\title{
AKAR TRADISI POLITIK SUFI ULAMA KALIMANTAN BARAT ABAD KE-19 DAN 20
}

\author{
Didik M Nur Haris \\ Rahimin Affandi Abdul Rahim \\ Akademi Pengajian Islam Universiti Malaya \\ email: didiknurharis@gmail.com, \\ faqir ila rabbih@,um.edu.my
}

Diterima: 26 Januari 2016. Disetujui: 01 April 2017

Dipublikasikan: Mei 2017

\begin{abstract}
Politics and Sufism, Two things that would never meet, There is a subjective view that the decline of Islam is due to the Sufis distancing themselves from the social and political activity. Historical facts prove that the Sufis who come to the archipelago have taught the real Islam and comprehensive in both the social, economic and political fields. This review will present historical evidence of the Sufi political tradition in the Indonesian archipelago and West Kalimantan in particular through the study of the third most popular ulamas of West Kalimantan in the 19th and 20th centuries namely AhmadKhatib alSambasi (1802-1879), Muhammad Basuni bin Muhammad 'Imran (1885-1953) dan Guru Haji Isma'il Mundu (1870 - 1957).
\end{abstract}

Keywords: Politik, Ulama Sufi, Kalimantan Barat

\section{A. Pendahuluan}

Terdapat satu pandangan di kalangan tarekat dan tasawuf bahwa sufi sejati adalah mereka yang anti dan menjauhkan diri (u₹lah) dari semua aktifitas sosial dan politik. Dalam 
pandangan mereka, konsep zuhd berarti kehidupan yang lebih berorientasi kepada urusan akhirat dibanding masalah dunia dengan menjauhkan diri dari masyarakat (khalwah dan u₹lab), dalam usaha mendekatkan diri kepada Allah SWT. 'Sebagian sarjana barat juga menyematkan sufi yang sebenarnya adalah mereka yang anti terhadap dunia dan fokus kepada keakhiratan. ${ }^{2}$

Pemikiran ini telah berdampak kepada pemahaman banyak kalangan muslim modernis, yang menganggap kesufian sebagai salah satu penyebab utama kemunduran dunia Islam. Mereka menuduh kesufian sebagai sumber bid'ah, tahayul dan khurafat. Secara sosial, kesufian telah dipersalahkan karena menarik masyarakat muslim ke arah "kepasifan" dan penarikan diri (uzlah) dari permasalahan duniawi. Ia dianggap menggalakkan sikap pelarian diri (escapism) dari kemunduran sosio-ekonomi-politik kaum muslimin. Akibatnya, masyarakat muslim tidak mampu bersaing dengan dunia Barat yang terus maju. $^{3}$

Realitas ini memangtidak dapat dipisahkan dari program-program kaum orientalis barat ${ }^{4}$ seperti Thomas Stamford Raffles (1781-1826), William Marsden dan Cristiaan

\footnotetext{
${ }^{1}$ Martin Van Bruinessen, "Tarekat Dan Politik: Amalan Untuk Dunia Atau Akherat?,” Majalah Pesantren, Vol. Ix No. 1, 1992), 6-7.

2John Bousfield, "Islamic Philosophy in Sout-East Asia”, dalam Islam in South-East Asia, ed. M.B. Hooker (Leiden: British Istitute in South East Asia, 1983), 105-117. Athur John Arberry. The Doctrine of the Sufis. England: Cambridge University Press, 1966), 9.Syed Naguib al-Attas.Some Aspects of Sufism; As understood and practiced among the Malays. Singapore: Malaysian Sociological Research Institute, 1963), h. 1.

${ }^{3}$ Shukri Ahmad, Ismail Yusoff \& Hamzah, Pendekatan Dakwah Ulama Sufi Nusantara Abad ke-17M dan 18M: Suatu AnalisisPerbandingan dengan Pendekatan Dakwah Ulama Malaysia Abad ke-21. Prosiding Nadwah Ulama Nusantara (NUN) IV: Ulama Pemacu Transformasi Negara. IV, 25-26 November 2011, h. 428.

${ }^{4}$ Segolongan sarjana-sarjana Barat yang mendalami bahasa-bahasa dunia timur dan kesusasteraannya, dan mereka juga menaruh perhatian besar terhadap agama-agamadunia timur, sejarahnya, adat istiadat dan ilmu-ilmunya. A. Hanafi, Orientalisme Ditinjau Menurut Kacamata Agama (Quran dan Hadits) (Jakarta: Pustaka al Husna, 1981), h. 9.
} 
Snouck Horgonje (1857-1936), ${ }^{5}$ mereka memalsukan, memutarbalikan ajaran-ajaran Islam, dan menyebarkan ilmu dan pemikiran yang subyektif tentang Islam seperti konsep zubd, khalwah dan uzlah, sufi dan tasawuf dan lain-lain.

Kajian ini akan membuktikan kesalahan tuduhan pemikiran diatas, dengan memaparkan berbagaibentuk peranan politikketiga ulama sufi yang populer di Kalimantan Barat pada abad ke-19 dan 20 yaitu AhmadKhatib al-Sambasi (1802-1879 M), Muhammad Basuni bin Muhammad 'Imran (1885-1953 M) dan Guru Haji Isma’il Mundu (1870 - 1957 M), bagaimana mereka mampu merumuskan hubungan yang harmoni antara Islam dan kekuasaan, agama dan negara, duniawi dan ukhrawi dalam sebuah tatanan konsep yang aplikatif.

\section{B. Pembahasan}

\section{Dotrin Politik Pada Masa Nabi}

Doktrin politik dalam Islam sesungguhnya merupakan konsep yang telah ada semenjak lahirnya Islam itu sendiri yang dibawa oleh Nabi Muhammad S.A.W., dimana keberadaan Rasulullah SAW disamping sebagai muballigh (penyampai wahyu), pemberi peringatan dan kabar gembira, beliau juga seorang Pemimpin dalam sebuah komunitas masyarakat, panglima dalam medan pertempuran dan juga Hakim dan referensi dalam segala permasalahan kehidupan sehari-hari yang dihadapi oleh umat, dimana semua aktifitas ini pada hakekatnya merupakan aktifitas politik dalam kontek kekinian. Rasulullah S.A.W. telah mengenalkan, mengajak dan menyeru kepada sebuah nilai, pemikiran dan prinsip-prinsip hidup yang baru yang bertentangan secara total dengan konsep, pemikiran dan keyakinan masyarakat Arab saat itu, aktifitas ini adalah aktifitas politik yang kita kenal di masa kini. Beliau telah meminta perlindungan kepada pemimpin-

\footnotetext{
${ }^{5}$ Harian Surat Kabar Republika, Islamia : Tokoh-tokoh Orientalis di Indonesia. Kamis, 13 Agustus 2009.
} 
pemimpin Thaif yaitu tiga bersaudara yang bernama: Abdul Yalail, Mas'ud dan Hubaib mereka adalah putra-putra dari Amr bin Umair bin Auf dari Bani Tsaqif. Beliau meminta suaka politik kepada Raja Najasyi dari Habsyah, aktifitas ini pada hakekatnya juga aktifitas politik yang kita kenal hari ini.Beliau mengambil janji setia kaum Anshar untuk membela hingga titik darah yang terakhir dalam peristiwa "Bai'atul Aqabah Kedua", aktifitas ini pada hakekatnya merupakan aktifitas politik.Beliau berhijrah mencari bumi subur untuk menyemaikan nilai-nilai Islam, membina umat dan komunitas masyarakat baru, mempersaudarakan diantara elemen masyarakat hingga beliau mengirim pasukan perang, melakukan perdamaian dalam peristiwa " Perjanjian Hudaibiyah", membangun basis-basis ekonomi, sosial, politik dan pertahanan keamanan, semua aktifitas-aktifitas ini hakekatnya aktifitas politik yang kita kenali di era moden. ${ }^{6}$

\section{Dotrin Politik Para Ulama Sunni}

Perkembangan doktrin politik Islam sangat dipengaruhi oleh kajian-kajian politik Islam yag dikembangkan oleh para pemikir klasik seperti Imam alMawardi (975-1058 M) dalam karyanya Nasibat al-Muluk dan al- Abkam al-Sultaniyyah, al-Ghazali (1058-1111 M)dalam karyanya al-Tibr al-Masbuq fi Nasihat al-Muluk dan Ibn Taimiyah (1263-1329 M) dalam karyanya al-Siyasah alShar'iyyah fi Islah al-Ra'i wa al-Ra'iyyah.

Kajian-kajian mereka dalam bidang politik Islam (siyasah syar'iyyah) merupakan satu bagian yang saling melengkapi dan menyempurnakan. Imam alMawardimengatakan bahwa, "Imamah (negara) dibentuk dalam rangka menggantikan posisi kenabian (nubuwwab) untuk melindungi

'Shafiyurrahman al-Mubarafuri, al-Rahiq al-Makhtum (Mesir: Dar alWafa, 1430 H/ 2009 M), h. 167-180. 
agama dan mengatur kehidupan dunia(al-imamah mawdu'ah li khilafat al-nubuwwah fibirasat al-din wa siyasat aldunya).'

al-Ghazali mengatakan : "kewaïban pembentukan negara dan pemiliban kepala negara, adalah berdasarkan kewajiban agama (Shari), bukan rasio. Kesejabteraan dan kebahagiaan akbirat tidak tercapai tanpa pengamalan dan penghayatan agama secara benar. Agama dan negara (pemimpin negara) bagaikan dua saudara kembar yang labir dari rahim seorangibu.Keduanya saling melengkapi. ${ }^{8}$

Menurut Ibn Taimiyah, "kesejabteraan manusia tidak dapat tercapai kecuali hanya dalam satu tatanan sosial di mana setiap orang saling bergantung dan membutubkan antara satu dengan yang lainnya. Oleb sebab itu dibutubkan seorang pemimpin yang akan mengatur kehidupan sosial tersebut'. ${ }^{9}$

Ketiga ulama klasik sunni telah merumuskan hubungan yang integral antara agama dan negara, meskipun mereka berbeda pendapat dalam landasan yang mendasari hukum pengelolaan negara dalam kontek syari'ah Islam. alMawardi berpendapat bahwa kewajiban menegakkan negara merupakan fardu kifayah yang dibina diatas dasar ijma' ulama.Pandangannya ini didasarkan pada realitas sejarah alKhulafa' al-Rashidun dan khalifah-khalifah sesudah mereka, baik Bani Umaiyah maupun Bani Abbasiyah.Dalam kaidah usul fiqh juga menyatakan bahwa "malayatimmu al-wajib illabihi fabuwa wajib" (suatu kewajiban tidak sempurna kecuali melalui sarana atau alat, maka sarana atau alat tersebut juga wajib hukumnya), artinya, menciptakan dan memelihara kemaslahatan adalah kewajiban umat Islam, sedangkan sarana atau alat untuk terciptanya kemaslahatan tersebut adalah negara, maka mendirikan negara juga wajib. ${ }^{10}$ t.th.), h. 5 .

${ }^{7}$ Abu al-Hasan al-Mawardi, al-Abkam al-Sultaniyah (Beirut: Dar al-Fikr,

${ }^{8}$ Al-Ghazali, al-Tibr al-Masbuk, fî Nasihat al-Muluk, terj.Ahmadie Thaha dan Ilyas Ismail (Bandung: Mizan, 1994), h. 136.

'Ibn Taimiyah, Minhâj al-Sunnah al-Nabawiyah, Juz 1 (Riyadh: Maktabat al-Riyad al-Hadithah, t.tp.), h. 23.

${ }^{10} \mathrm{Abu}$ al-Hasan al-Mawardi, Op. Cit. 
Sejalan dengan pendapat al-Mawardi, imam al-Ghazali memandang bahwa kewajiban pembentukan negara dan pemilihan kepala negara adalah berdasarkan kewajiban agama (Syari), bukan logika. Menurutnya Agamadan negara (pemimpin negara) bagaikan dua saudara kembar yang lahir dari rahim seorangibu.Keduanya saling melengkapi. ${ }^{11}$

Berbeda dengan kedua ulama sunni sebelumnya, Imam Ibnu Taimiyyah melihat bahwa kesejahteraan manusia tidak dapat tercapai kecuali hanya dalam satu tatanan sosial dimana setiap orang saling memerlukan antara satu dengan yang lainnya. Oleh sebab itu diperlukan seorang pemimpin yang akan mengatur kehidupan sosial tersebut. Menurut pandangan Ibnu Taimiyyah pembinaan institusi negara bukanlah atas dasar agama, melainkan hanya kebutuhan praktis saja. Meski ia mengakui bahwa kesejahteraan umat Islam tidak mungkin dapat tercipta baik di dunia maupun di akhirat kecuali melalui institusi negara. ${ }^{12}$

\section{Tradisi Politik Sufi di Nusantara}

Tradisi politik sufi ini juga tampak dengan jelas dari semenjak proses Islamisasi di kawasan Nusantara yang dibawa oleh para ulama tasawuf, ${ }^{13}$ tidaklah berlebihan jika kita menyimpulkan bahwa Islamisasi kawasan Nusantara merupakan sebuah gejala dan fenomena politik. Konversi raja-raja Melayu di Nusantara ke dalam agama Islam merupakan kekuatan politik yang berperan sangat signifikan dalam pengislaman masyarakat kerajaan Nusantara. Dalam perkembangan berikutnya, setelah Islam mulai berakar dalam masyarakat, peran saudagar muslim dalam penyebaran Islam digantikan dan diambil alih oleh ulama. Mereka bertindak

${ }^{11}$ Al-Ghazali, Op. Cit.

${ }^{12}$ Ibn Taimiyah, Op. Cit.

${ }^{13}$ Syed Naguib al-Attas, Some Aspects of Sufism: As Understood and Practised Among the Malays, (Singapore: Malaysian Sociological Rasearch Institute Ltd. 1963), h. 24-26. Alwi Shihab, Islam Sufistik, Islam Pertama dan Pengarubnya Hingga Kini di Indonesia, (Bandung: Mizan, 2001). 
sebagai guru dan penasihat raja atau sultan.para ulama dan pendakwah yang datang semenjak awal di kawasan nusantara, sebagaimana yang pernah dirumuskan oleh ulama-ulama Sunni klasik. Tradisi politik ini semakin menguat sejalan dengan kuatnya pengaruh ulama di kerajaan-kerajaan Nusantara. ${ }^{14}$

Nuruddin al-Raniri (w. 1068 H/1658 M) misalnya, ia merupakan penasihat Sultan (Shaykh al-Islam). daripada Sultan Iskandar Tsani di Aceh (1636-1642 M), bahkan pada masa pemerintahan pengganti Iskandar Tsani, Sultanah Safiatuddin Taj al-Alam (1642-1675 M), posisi al-Raniry sangat kuat tidak hanya dalam bidang agama, namun juga dalam masalahmasalah politik, ekonomi dan lainnya. ${ }^{15}$ Raja Ali Haji (1808 1973 M) telah dilantik menjadi penasihat agama kerajaan pada tahun 1845, semassa Raja Ali bin Raja Jafar diangkat menjadi Yang dipertuan Muda. Pada tahun 1858, ketika Yang Dipertuan Muda Riau IX Raja Abdullah Mursyid wafat, maka Raja Ali Haji diberi amanat untuk mengambil alih segala urusan hukum. ${ }^{16}$

Tradisi pengkaryaan dalam bidang politik juga telah ada pada awal-awal Islam di nusantara, seperti Bukhari alJawhari menulis Taj al-Salatin (1603), al-Raniri (1658) dengan karyanya Bustan al-Salatin, Raja Ali Haji (1873) Thamarat alMubimmah Diyafah li al-Umara' wa al-Kubara' li Abl alMabkamah (Buah-buahan yang dicita-cita hal keadaan jadi jamuan bagi raja-raja dan bagi orang-orang besar yang mempunyai pekerjaan di dalam tempat berhukum) yang Ia telah siap ditulis pada 1275/1857 namun terbit pertama kali di Lingga pada tahun 1304/ 1886. ${ }^{17}$

${ }^{14}$ Muhammad Iqbal, Akar Tradisi Politik Sunni di Indonesia pada masa kerajaan Islam di Nusantara. ISLAMICA, Vol. 6, No. 1, September 2011, 61.

${ }^{15}$ Ibid.

${ }^{16}$ Khalif Muammar A. Harris, "Ilmu Ketatanegaraan Melayu Abad Ke-19: Kajian Terhadap Karya Raja Ali Haji," (Sari - International Journal Of The Malay World And Civilaisation. 29 (1) (2011), h. 82-83.

${ }^{17}$ Khalif Muammar A. Harris, Op.Cit, 81. 


\section{Tradisi Politik Sufi di Kalimantan Barat}

Kalimantan Barat telah dikenali sejak dahulu sebagai kawasan pusat penyebaran dakwah Islam.Di kawasan ini terdapat 21 kesultanan Islam yang masih dapat diketemukan bukti-bukti arkeleoginya sehingga kini. ${ }^{18}$ Kepesatan penyebaran Islam di kawasan ini, tidak dapat dipisahkan dari adanya jaringan ulama-ulama Nusantara dan ulama-ulama Mekah yang telah terjalin mesra sejak abad ke-17 berawal dari Nur al-Din al-Raniri (w.1666), Abd Rauf al-Singkili (16201695) dan Yusuf al-Maqassari (1626-1699). Seterusnya di susul oleh Muhammad Nafis al-Banjari (L.1735), Dawud alFatani (1718-1847) dan lainnya telah membawa dampak hebat terjadinya proses pembaruan di kawasan ini. ${ }^{19}$

${ }^{18}$ Diantara kesultanan-kesultanan Islam yang pernah berdiri adalah (1).Istana Matan di Kota Ketapang abad ke-16, (2).Istana Sukadana di Kabupaten Ketapang abad ke-16, (3).Istana Simpang (Melano) di Kabupaten Ketapang abad ke-16, (4).Istana Kendawangan di Ketapang abad ke-16, (5).Istana Kubu di Kabupaten Kubu Raya abad ke-19, (6).Istana Amantu Billah di Mempawah abad ke-18, (7).Istana Al Watiqu Billah di Sambas abad ke-17,18 (8).Istana Kadriah di Kota Pontianak abad ke-16, (9).Istana Landak di Ngabang sejak tahun 1472 M, (10).Istana Tayan di Kabupaten Sanggau abad ke-19, (11).Istana Kuta di Kabupaten Sanggau abad ke-19, (12).Istana Beringin di Kabupaten Sanggau abad ke-19, (13).Istana Sekadau di Kabupaten Sekadau abad ke-19, (14).Istana Sintang di Kota Sintang abad ke-18, (15) Istana Nanga Silat di Kabupaten Kapuas Hulu abad ke-19, (16).Istana Semitau di Kabupaten Kapuas Hulu abad ke-19, (17).Istana Jongkong di Kabupaten Kapuas Hulu abad ke-19, (18).Istana Selimbau di Kabupaten Kapuas Hulu abad ke19, (19).Istana Nanga Suhaid di Kabupaten Kapuas Hulu abad ke-19, (20).Istana Nanga Bunut di Kabupaten Kapuas Hulu abad ke-19, (21).Istana Piasak di Kabupaten Kapuas Hulu abad ke-19. Tim Peneliti Universitas Tanjung Pura (UNTAN), h. Pontianak: Istana di Kalimantan Barat, (Untan, 2000), h. 2. Pabali Musa, "Latar Belakang Sosial Politik Tarekat Qadiriyah wa Naqsyabandiyah Ahmad Khatib Sambas", (Disertasi pasca sarjana, UIN, Jakarta, 2008), h. 19.

${ }^{19}$ Menurut Azra, ulama al-Raniri dan al-Singkili abad ke-17 dan Muhammad Arsyad al-Banjari dan Dawud al-Fathani abad ke-18, sangat membantu perkembangan keilmuan Islam di Nusantara dengan karya-karyanya yangberedar luas di Nusantara. diantaranya al-Shirat al-Mustaqim karya al-Raniri, Mir'ah al- Thullab fi Tashil Ma'rifah al-Ahkam al-Shar'iyyah li al-Malik alWahhab, Kitab al-Faraidl karya Abd al-Ra'uf al-Singkeli, Sabil al-Muduhtadin karya Muhammad Arsyad al-Banjari. Hidayat al-Salikin fi Suluk Maslak alMuttaqin dan Siyar al-Salikin ila 'Ihadat Rabb al-'Alamin karya Abd al-Samad al- 
Pada akhir abad ke-19 dan awal abad ke-20 terdapat ulama-ulama yang menjadi rujukan tidak saja ulama-ulama Nusantara namun juga ulama-ulama dunia Islam pada umumnya. Diantaranya adalah AhmadKhatib al-Sambasi (1802-1879 M), Muhammad Basuni bin Muhammad 'Imran (1885-1953 M) dan Guru Haji Isma’il Mundu (1870 - 1957 M).

\section{Akar Politik Ahmad Khatib al-Sambasi (1802-1879 M)}

Ahmad Khatib al-Sambasi adalah diantara ulama yang memiliki pengaruh cukup hebat dalam menyebarkan ajaran tarekat bahkan telah berhasil memadukan antara tarekat Qadiriyah dan tarekat Naqshabandiyah sehingga lebih dikenali dengan Tarekat Qadiriyyah Naqshabandiyyah (TQN). ${ }^{20}$ Ide cemerlang dan usaha penyatuan Tarekat Qadiriyah dan Tarekat Naqshabandiyah sesungguhnya merupakan langkah politik besar untuk merancang, mengurus, mengendalikan, dan menjaga kemaslahatan serta menjauhkan keburukan, ini merupakan hakekat inti dantujuan utama aktifitas politik dalam syariah Islam (siyasah syar'iyyah), sebagaimana yang dikemukakan Ibn 'Āqil yang menyatakan Siyāsah syar iyyah ialah : "Suatu tindakan oleh pemimpin yang boleh menyelamatkan orang ramai dan menghindarkan mereka dari kehancuran, walaupun tindakan tersebut tidak dilakukan oleb

Falimbani, Sabil al-Muhtadin karya Sheikh Muhammad Arshad al-Banjari, Bughyah al-Tullab al-Murid Ma'rifat al-Ahkam bi al-Sawab, Furu' al-Masail wa Usul al-Masail, Jami' al- Fawaid, Hidayat al-Mut'allim wa 'Umdat al-Mu'allim, Muniyyat al-Musalli, Nahj al-Raghibin fi sabil al-Muttaqin, Ghayat al-Taqrib dan Idlah al-bab li Murid al-Nikah bi al- Shawab karya Dawud bin Abdullah bin Idris al-Fatani. rujukan-rujukan utama karya-karya ulama-ulama timur Tengah seperti Syarh Minhaj al-Thullab karya Syams al-Din al-Ramli, Nihayat al-Muhtaj ila Syarh al-Minjhaj karya al-Nawawi, tuhfat al-Muhtaj ila Syarh al-Minhaj karya Ibn Hajar al-Haithami, Mughni al- Muhtaj karya Khatib al -Syarbini. Lihat dalam Azyumardi Azra, Jaringan Ulama Timur Tengab dan Kepulauan Nusantara Abad XVII dan XVIII,c. 2, (Bandung: penerbit Mizan, 1995), h. 225-340.

${ }^{20}$ Syed Naquib al-Attas menyebut Ahmad Khatib Sambas sebagai Shaikh dari kedua tarekat tersebut. Syed Naquib al Attas, Op. Cit., 33. 
Rasulullah s.a.w. atau pun tidak ada wabyu berkenaan perkaratersebut". ${ }^{21}$ Sehingga tidaklah mengherankan jika sebagian sarjana mengemukakan bahwa formulasi dan penyatuan ajaran tarikat Qadiriyah Naqsyabandiyah lebih merupakan pertimbangan yang lebih bersifat politik iaitu pertama, dengan penyatuan ini diharapkan akan mengembalikan semangat awal berdirinya tarekat itu sendiri iaitu sebagai suatu gerakan sosial yang dinamis untuk melawan keadaan lingkungan yang tidak ideal, kedua, jika penyatuan ini terhasil, maka dapatlah dipastikan bahwa seluruh dunia Islam ketikaitu bersatu dalam satu kepemimpinan. ${ }^{22}$ Apa yang dilakukan oleh Ahmad Khatib dalam langkah penyatuan ini juga tidak dipisahkan darirealitas geo-sosial politik yang sedang berkembang saat itu,realitas pertama, kondisi sosial politik ummat Islam yang menghadapi gelombang tantangan yang besar baik dari eksternal maupun internal, tantangan eksternal paling besarmuncul dari kolonialisme penjajahan yang menguasai di hampir seluruh dunia Islam termasuk di kawasan Nusantara, tidak hanya tantangan yang bersifat politik dan kekuasaan, namun di dalamnyaterkandung tantangan misi kristenisasi dan program sekularisasi ${ }^{23}$, dengan menjadikan Islam dalam sebuah rumusan yang sempit, pertama, Islam hanya terbatas dalam bidang agama murni (ibadah), kedua, di bidang sosial kemasyarakatan pemerintah kolonial memanfaatkan hukum adat sebagai sebuah aturan dalam perundangan, ketiga, di bidang politik pemerintah kolonial harus mencegah setiap usaha yang akan membawa rakyat kepada fanatisme politik pan-Islam. ${ }^{24}$

\footnotetext{
${ }^{21}$ Ibn Qayyim al-Jawziyyah, al-Turuq al-Hukmiyyah Fì al-Siyāsah alSyariyyah, 11.

${ }^{22}$ Pabali Musa, Op. Cit,179.

${ }^{23}$ Sekularisme merupakan paham yang memisahkan peran antara agama dan negara; sakral dan profan; duniawi dan ukhrawi. Syed Muhammad Naquib al-Attas, Risalab Untuk Kaum Muslimin, (KualaLumpur: ISTAC, 2001), h. 197-199 12.

${ }^{24}$ Aqib Suminto, Politik Islam Hindia Belanda (Jakarta: LP3ES, 1996), h.
} 
Secara internal, Ahmad Khatib melihat secara langsung sepanjang hayatnya di Mekah kondisi yang sangat memprihatinkan, khususnya perebutan kekuasaan antara kesultanan Turki Uthmani, Dinasti Saudi dan penguasa Mesir Muhammad Ali Pasa selama kurun 1804-1849, ${ }^{25}$ sedangkan dalam gerakan keagaamaan seperti tarekat, munculnya hubungan yang tidak harmoni akibat perebutan pengaruh yang berdampak kepada timbulnyaperselisihan yang hebat. Martin Bruinessen menuliskan bahwa perselisihan dan persaingan tidak sehat ini, tidak saja terjadi di Mekah dan Madinah, namun juga terjadi antar murid-murid mereka di Indonesia dengan melemparkan tuduhan bahwa pihak lawannya telah menyimpang dari ajaran tarekat naqshabandiyah yang sebenarnya, persaingan ini sesungguhnya lebih disebabkan oleh motif keuntungan secara ekonomi. Beberapa surat mereka disita oleh pemerintah Belanda seperti dalam MGS 23-5-1886, No 91 c (Arsip Nasional) yang ditandatangani oleh Muhammad Sa'id Gusti Banjar (semasa itu adalah Kalimantan Tenggara) dan Abd Rahman, Muhammad Yunus bin Abd Rahman dan Zain alDin Rawa (Sumatera tengah) telah merekam beberapa bukti fenomena ini. ${ }^{26}$

Di sisi lain, doktrin-doktrin tasawuf tentang Khalifat Allah fi al-Ard serta konsep bai'atdalam membina ikatan antara guru atau mursyid dengan murid-muridnya, yang sesungguhnya formulasi ajaran yangmengadopsi dari konsep politik dalam pemerintahan Islam melalui sistem Khilafah Islamiyah sangat berpengaruh terhadap implementasi ajaranajaran tasawuf dalam menghadapi realitas dan dinamika kehidupan.

Apa yang telah dilakukan oleh Ahmad Khatib telah memberikan warna baru dalam kajian tasawuf, sehingga

${ }^{25}$ Badri Yatim, Sejarah Sosial Keagamaan Tanab Suci Hijaz, Mekekah dan Madinah) 1800-1925 (Ciputat: Logos, 1999), h. 131-134.

${ }^{26}$ Martin Bruinessen, Tarekat Naqsybandiyah di Indonesia (Bandung: Mizan, 1992), h. 68-69. Pabali, Op. Cit, 172-173. 
dalam perkembangannya, di setengah kedua abad ke-19, tarekat Ahmad Khatib Sambas tampil sebagai sarana dalam penyebaran Islam di seluruh Indonesia dan dunia Melayu, ${ }^{27}$ tarekat Ahmad Khatib juga menjadi faktor pembangkit lahirnya semangat aktifisme dan heroik yang tinggi. Muridmurid dariAhmad Khatib Sambas lahir berperan dalam berbagai aspek kehidupan baik dalam aspek pendidikan dengan lahirnya institusi pesantren yang tersebar di hampir keseluruhan pulau jawa, pada aspek sosial, tarekat Ahmad Khatib telah menginspirasi pembinaan banyak organisasi sosial masyarakat seperti Nabdlah al-Ulama (NU) yang didirikan oleh salah satu cucu murid Syeikh Ahmad Khatib yaitu Syeikh Hasyim 'Ash'ari. Bahkan dari salah satu murid kesayangannya yang dilantik sebagai wakil Khalifahnya di Nusantara yaitu Syeikh 'Abdul Karim al-Bantani telah memimpin satu perjuangan melawan kolonial Belanda di penghujung abad ke-19.28

Realitas ini tidak dapat dipisahkan dari pengaruh geneologi keilmuan dan intelektual yang diterima oleh Ahmad Khatib al-Sambasi, terutama Syeikh Daud bin Abdullah alFatani(1720-1843) yang banyak memberikan pengaruh kepada kepribadian Ahmad Khatib, Syeikh Daud al-Fathani merupakan ulama Nusantara yang popular pada akhir abad ke-18 dan awal ke-19, beliau lahir di Kerisik di lingkungan Istana sultan Patani pada tahun 1131 H/1720 M, Ia sangat produktif dalam penulisan dan pengkajian,Wan Mohd Shaghir telah mencoba mengumpulkan hasil-hasil karyanya tidak kurang daripada 66 judul buku, bahkan menurut beliau Daud al-Fatani telah menulis 99 kitab atau menurut pendapat lain

\footnotetext{
${ }^{27}$ Srimulyati.Tasawuf Nusantara Rangkaian Mutiara Sufi Terkemuka, (Jakarta: Kencana Prenada Media Group, 2006), h. 179.

${ }^{28}$ Yaitu pemberontakan petani Banten pada tahun 1888. Lihat dalam Sartono Kartodirdjo, "The Peasants' Revolt of Banten in 1888: The Religious Revival," dalam Reading on Islam in Southeast Asia, Ahmad Ibrahim et al., (Singapore: Institute of Southeast Asia Studies, 1985), h. 106. Pemberontakan Petani Banten 1988, Kondisi, Jalan peristiwa, dan Kelanjutannya: Sebuab Studi mengenai Gerakan Sosial di Indonesia, ed. Hasan Basari, (Jakarta: Pustaka Jaya, 1984), h. 20.
} 
hingga 101 kitab, selebihnya belum diketahui judulnya,tidak saja aktif dalam penulisan, Syeikh Daud juga terlibat dalam peperangan jihad fi sabilillah. ${ }^{29}$

Di sisi lain, ciri khas teknik berzikir tarekat Qadiriyah yang diucapkan dengan suara keras serta diiringi gerak yang bersemangat baik berdiri maupun duduk, sudah tentu akan dapat membangkitkan semangat heroik dan sangat cocok bagi para pejuang. ${ }^{30}$

\section{Akar Politik Muhammad Basuni Imran (1885-1953} M)

Syeikh Muhammad Basuni Imran merupakan tokoh pembaharu abad ke-20 di kawasan Kalimantan Barat, ia hidup sezaman bahkan seguru dengan beberapa tokoh pembaruan Indonesia lainnya seperti K.H. Ahmad Dahlan (lahir 1869) pendiri Muhammadiyah, K.H. Hasyim Asy`ary (lahir 1887) pendiri Nabdhatul-Ulama (NU), G.F. Pijper mengatakan: "Pandangan H. Muhammad Basuni Imran telah mewakili reformasi Mesir dengan sebenar di Indonesia". ${ }^{31}$ Syeikh Muhammad Basuni Imranhampir di sebagian besar masa hidupnya berhubungan dengan jabatan-jabatan penting dalam pemerintahan kesultanan Sambas, diantaranya pertama, Maharaja Imam di kesultanan Sambas (1913-1946 M), adalah Jabatan yang paling masyhur, Kedua, Kepala Madrasah al-Sultaniyah (1919-1935 M), pada masa Sultan Muhammad Shafiyuddin II, yaitu lembaga pendidikan di lingkungan istana yang memberikan pendidikan dasar agama dan ilmu-ilmu umum bagi kerabat sultan, anakanak pejabat kesultanan dan masyarakat di kawasan istana, ketiga,Adviseur Cammissie voor ZelfBestuur (1946-1950 M) yaitu jabatan resmi penasehat pemerintahan otonomi di Sambas

${ }^{29}$ Wan Mohd Shaghir Abdullah, Penyebaran Islam dan silsilab ulama sejagat dunia Melayu, Seri 11 (Kuala Lumpur: Persatuan Pegkajian Khazanah Klasik Nusantara dan Khazanah Fathaniyah, 2000), h. 7-12.

${ }^{30}$ Pabali Musa, Op. Cit, 116.

${ }^{31}$ G.F.Pijper, Studien Over de Geschiedenis Van De Islam In Indonesia 19001950, (Netherlands: E.J. Brill Leiden, 1977), h. 134. 
dari pemerintahan Belanda, keempat, Penata hukum tingkat I atau kepala pengadilan agama Mahkamah syariah Kalimantan Barat (1966-1975 M) dan kelima, anggota Konstituante Republik Indonesia wakil daripada partai Masyumi (Majelis Syuro Muslimin Indonesia) Kalimantan Barat hasil dari pemilu I, tahun 1955. ${ }^{32}$

Diantara terobosan yang cukup penting ketika menjabat sebagai Maharaja Imam mufti kerajaan Sambas adalah reformasi birokrasi lembaga keimaman, seperti yang tampak dalam skema gambar berikut: ${ }^{33}$

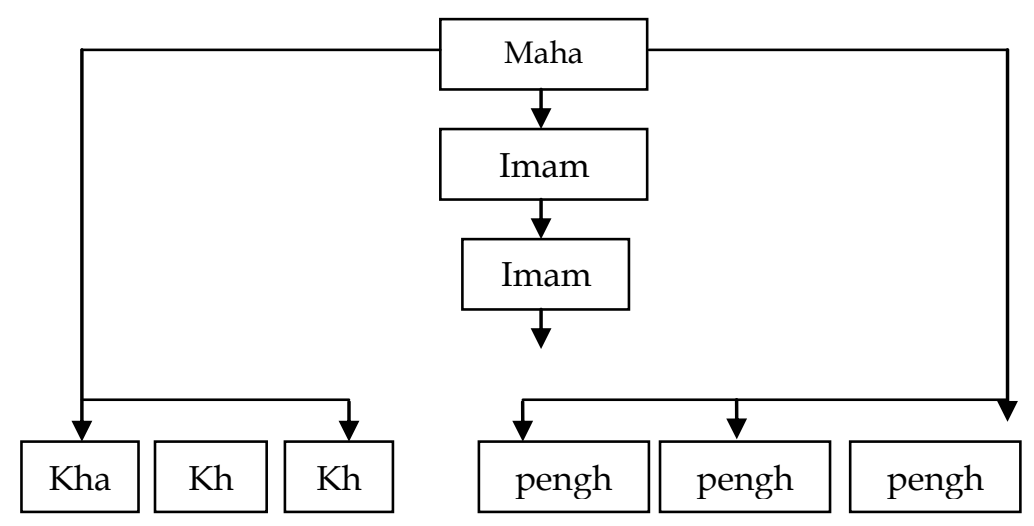

Dari skema gambar di atas, tampak jelas bahwa mulai dari Maharaja Imam, Imam Maharaja dan Imam merupakan jabatan tertinggi yang berkedudukan di pusat kerajaan, sedangkan khatib dan penghulu berkedudukan di desa dan kampung bertanggung jawab langsung kepada Maharaja Imam. Imam Maharaja merupakan wakil dari Maharaja Imam, sedangkan Imam dan Khatib adalah petugas dalam pelaksanaan shalat jumat di masjid-masjid, adapun penghulu bertugas dalam hal pencatatan perkawinan.

${ }^{32}$ Machrus Effendy, Riwayat Hidup dan Perjuangan Maba Raja Imam Sambas, 29-30. Pabali, "Muhammad Basuni Imran (1883-1976), b. Rekonstruksi Pemikiran Maharaja Imam Sambas-Kesultanan Sambas Kalimantan Barat(Tesis Program Magsiter Pemikiran Islam, IAIN Syarif Hidayatullah, 1999), h. 46.

${ }^{33}$ Ibid. 
Yang cukup menarik dari tradisi politik yang dimainkan oleh Muhammad Basuni Imran adalah sikap kooperatif dan jalur kerjasama dalam pengelolaan pemerintahan yang sejak tahun $1813 \mathrm{M}$ telah berada di bawah kekuasaan kolonial Inggris, kemudian sejak $1818 \mathrm{M}$ di bawah kekuasaan penjajah Belanda dengan didirikannya kantor perwakilan Belanda di Sambas. ${ }^{34}$

Kepiawaian Muhammad Basuni Imran dalam pengelolaan ketatanegaraan tidak lahir secara tiba-tiba, namun tumbuh dan berkembang dari sebuah tempaan lingkungan,kakek Muhammad Basuni Imran yaitu $H$. Muhammad Arif merupakan Maha raja Imam pertama di kesultanan Islam Sambas, sedangkan H. Muhammad Imran ayahanda Muhammad Basuni Imran merupakan Maha raja Imam kedua di kesultanan Islam Sambas, lingkungan ini sangat besar memberikan warna dan pengaruh dalam membentuk kepribadian dan pola fikir Muhammad Basuni Imran. ${ }^{35}$ Pertemuanya dengan beberapa tokoh reformis dunia Islam seperti Sayid Muhammad Rasyid Rida, pemilik majalah "al-Manar", guru Muhammad Basuni Imran ketika di Mesirmerupakan tokoh reformis yang merepresentasikan pemikiran-pemikiran Muhammad Abduh dan Jamaludin alAfgani,juga turut andil dalam membentuk kecerdasan politik (political intelligence) Muhammad Basuni Imran. Komunikasi diantara kedua tokoh reformasi ini tetap terjalin sehingga ketika Muhammad Basuni Imran kembali dan pulang di tanah air, berbagai permasalahan umat Islam yang sedang mendera menjadi salah satu topic perhatian dan perbincangan yang serius, hal tampak dari salah satu surat Muhammad Basuni Imran yang dikirimkan kepada sang guru di majalah al-Manar tentang"Limadha taakhar al-Muslimuna wa limadha taqaddama

\footnotetext{
${ }^{34}$ Irwin, Borneo Abad Kesembilan Belas. Terj. Mohd. Nor Ghani dan Noraini Ismail, c. 2, (Kuala Lumpur: Dewan Bahasa dan Pustaka, 2006), h. 3363.

${ }^{35}$ G. F. Pijper, Beberapa Studi tentang Sejarah Islam di Indonesia1900-1950, terj. Tudjimah \& Yessy Augusdin (Jakarta: UI Press, 1984), h. 142.
} 
ghairubum?" (Mengapa Ummat Islam mundur dan orang lain maju?)", pertanyaan ini kemudian menjadi buku dengan judul yang sama, yang ditulis oleh Amir Shakib Arselan (18691945), buku ini kemudian diterjemahkan kedalam bahasa Inggris berjudul "Our Decline and its Causes" terbit di Lahore Pakistan tahun 1944,36 dan terjemahan ke dalam bahasa Indonesia diterbitkan pada tahun 1970-an.

Atas berbagai jasa dan kerjasamanya dengan pemerintah Hindia Belanda, Syeikh Muhammad Basiuni Imran mendapatkan beberapa penghargaan dari pemerintah Belanda, seperti, Plaatselijk (Piagam Penghargaan, 1920), dan Ridder in de Orde van Oranje-Nassau dari Ratu Wilhelmina, 13 September 1946. ${ }^{37}$

\section{Akar politik Guru Haji Isma'il Mundu (1870 - 1957} M)

Guru Haji Isma'il Mundu merupakan ulama kharismatik yang cukup popular di Kalimantan Barat, ia sezaman dengan Muhammad Basuni Imran bahkan seperguruan, ia bertemu dalam silsilah geneologi keilmuan Muhammad Basuni Imran dan Syeikh Umar daripada Sumbawa. ${ }^{38}$ Ia dikenali sebagai ulama tasawuf melalui ajaranajaran tasawufnya yang terdapat dalam karyanya Kitab Drikir Taubidiyah. ${ }^{39}$

${ }^{36}$ G. F. Pijper, Op. Cit., 148-149.

${ }^{37}$ A. Muis Ismail, Mengenal Mubammad Baisuni Imran (Mabaraja Raja Sambas) (Pontianak: FISIP Universitas Tanjungpura, 1993), h. 19, Machrus Effendi, Op. cit, 16. G. F. Pijper, Op. Cit, 145.. Pabali, Op. Cit, 7.

${ }^{38}$ M. Riva'I Abbas et al., Biografi Guru Haji Isma'il Mundu,Mufti Kerajaan Kubu. C. 2 (Pontianak: Kitara Creativision, 2008), h. 12

${ }^{39}$ Kitab ini diselesaikan pada 1 Muharam $1349 \mathrm{H}$ diterbitkan Matba'ah Sayyid Alaydrus Keramat 38, Jakarta.Kitab ini mengandungi zikir-zikir yang diamalkan oleh Guru Haji Isma'il Mundu beserta murid-muridnya yang telah mendapati ijazah (pengiktirafan untuk mengamalkannya). Kitab ini pada mulanya merupakan tulisan tangan dari Guru Haji Isma'il Mundu, namun pada akhirnya ianya dicetak kembali oleh Muhammad bin Yahya Alawy. Didik M Nur Haris, "Kitab Jadual Nikah karya Guru Haji Isma'il Mundu; Teks dan Analisis" (Tesis Jabatan Fiqh dan Usul Universiti Malaya Malaysia, 2011), h. 42-43. 
Kemasyhurannya semakin hebat ketika Guru Haji Ismail Mundu terlibat dalam jabatan mufti pemerintahan kerajaan Islam Kubu semenjak pemerintahan Raja Syarif Abbas, yaitu raja yang keenam (1900-1911), jabatannyaia duduki sehingga kali yang ketiga. Selain dari itu, berdasarkan surat tertanggal Pontianak, hari Kamis, 13 Februari 1936 H bertepatan 20 Zulhijjah 1354 M, Syeikh Guru Haji Ismail Mundu dilantik sebagai tokoh tertinggi yang menangani urusan Islam di kerajaan Pontianak dan kerajaan-kerajaan kecil di bawah kekuasaannya. ${ }^{40}$ Sejalan dengan tradisi politik yang diambil oleh Muhammad Basuni Imran, Guru Haji Isma'il juga memilih bekerjasama dalam pengelolaan pemerintahan yang tidak lagi secara penuh dalam kekuasaan kesultanan Kubu, namun telah jatuh dalam wilayah kekuasan Hindia Belanda sejak27 Agustus 1849.41 Ia bahkan menerima bintang jasa dan honorarium pemerintah Belanda daripada Ratu Wihel Mina sebagai sebuah tanda terimakasih dan penghargaan yang tinggi pada tahun 1930.42

Keterlibatannya dalam kancah politik praktis tidak terpisah dari darah kebangsawanan yang mengalir dalam dirinya, Guru Haji Isma'il Mundu merupakan keturunan dari Raja Sarwito yang merupakan keturunan raja-raja Gowa Sulawesi Selatan. ${ }^{43}$ Darah kebangsawanan ini semakin terasah ketika ia berguru kepada Syeikh Ahmad al-Zawawi, mufti mazhab Shafi'i di Mekah, pada masa pemerintahan Sharif Husein, beliau pernah menduduki jabatan ketua majelis Shura,

\footnotetext{
${ }^{40}$ Wan Mohd Shaghir, Wawasan Pemikiran Islam Ulama Asia Tenggara, j.6 (Kuala Lumpur: Persatuan Pengkajian Khazanah Klasik Nusantara dan Khazanah Fathaniyah1425 H/2004 M), h. 73-74.

${ }^{41}$ Belanda, wester-afdeeling berdasarkan Bêsluit van den Minister van Staat, Gouverneur-Generaal van Nederlandsch-Indie, pada 27 Agustus 1849, No. 8 dan No. 40

${ }^{42}$ M. Riva'i Abbas et al.,Op. Cit, 13

${ }^{43}$ Ibid. h. 7.
} 
ketua majelis shuyukh dan ketua 'ain Zubaidab'44.Kedekatan keduanya sangat terlihat dari fakta sejarah adanya surat panggilan dari putra Sheikh Abdullah al-Zawawi yaitu Muhammad bin Abdullah al-Zawawi tertanggal 15 Safar 1340 $\mathrm{H}$ yang memohon kepada Guru Haji Isma'il Mundu untuk berziarah ke Makkah al-Mukarramah. ${ }^{45}$ Persahabatannya dengan berbagai kalangan tokoh dan ulama Nusantara seperti Alawi bin Tahir bin Abdullah al-Haddad mufti kerajaan Johor dan Abbas bin Muhammad Taha pejabat Qadli Qudlat Singapura, dan juga Sayyid Hasan Jufri seorang mufti Hadramaut yang pernah berkunjung ke kesultanan Kubu, akan sangat memberikan pengaruh yang besar dalam pemikiran dan kepribadiannya. ${ }^{46}$ Ketokohannya dalam kancah politik semakin tampak jelas dari kunjungan resmi utusan presiden pertama Republik Indonesia Ir. Soekarno kepada Guru Haji Ismail Mundu untuk meminta pandangan dan solusi terhadap masalah-masalah bangsa. ${ }^{47}$

\section{Transformasi Politik Oposisi kepada Politik Koalisi}

Terdapat fakta yang cukup menarik dalam tradisi politik ketiga ulama Kalimantan Barat abad ke-19 dan 20, dimana Ahmad Khatib al-Sambasi di abad ke-19 meskipun ia tidak terlibat dalam politik praktis, namun gerakan tarekat Qadiriyyah Naqsyabandiyahnya telah tampil sebagai sarana untuk melakukan gerakan perlawanan terhadap kekuasaan kolonial seperti yang tampak dari salah satu murid yang dilantik sebagai wakil Khalifahnya di Nusantara yaitu Syeikh 'Abdul Karim al-Bantani yang telah memimpin satu perjuangan melawan kolonial Belanda di penghujung abad ke19. Fakta ini sebagaimana dikemukakan oleh sebagian peneliti

${ }^{44}$ Umar 'Abd Jabbar, Kitab Siyar wa al-Tarajim ba'd ulamaina fi al-Qarn alRabi' al-'Ashr min al-Hijrah, c. 3.Jedah:Tihamah al-Kitab al-Arabi al-Su'udi, 1403 H/1982 M), h. 140.

${ }^{45}$ M. Riva'i Abbas et al., Op. Cit, 21

${ }^{46}$ Ibid.

${ }^{47}$ H. M. Riva'i H. Abbas et al, Op. Cit, 24. 
tidak dapat dipisahkan dari geopolitik yang penuh pergolakan baik skala regional maupun internasional. Pada tingkat regional Inggris dan Belanda saling bertarung memperebutkan wilayah dagang di Nusantara yang berlangsung sejak abad abad ke-17 dan puncaknya pada awal abad ke-19, sedangkan pada tingkat internasional pada abad ke-19 tantangan kolonialisme semakin meningkat di negaranegara Muslim, tahun 1770 Rusia telah mulai menguasai Turki, penguasaan ini telah menjadi babak baru penguasaan wilayah-wilayah Islam di Asia Tengah. ${ }^{48}$ Tidak lama kemudian pada Juli tahun 1798 Napoleon Bonaparte menduduki Mesir, pola kepemimpinan Napoleon yang otoriter telah menjadi faktor yang membangkitkan perlawanan rakyat Mesir yang demikian hebat. ${ }^{49}$ Konstalasi geopolitik yang memanas baik ditingkat regional maupun internasional ini yang menjadi pertimbangan utama jaringan tarekat Qodiriyah Naqsyabandiyah sebagai sarana gerakan perlawanan terhadap kekuasaan kolonial.

Tradisi politik ini mengalami transformasi yang sangat mendasar pada abad ke-20, dimana kedua ulama Kalimantan Barat yang populer pada abad ini yakni Muhammad Basuni Imran dan Guru Haji Isma'il Mundu lebih memilih sikap kooperatif dan bekerjasama dalam lingkungan pemerintahan yang berada dalam kekuasaan kolonial. Tradisi politik ini yang dikenali dalam kajian ilmu politik modern sebagai koalisi.Pilihan ini sangat mungkin dilatarbelakangi oleh beberapa pertimbangan, pertama, pertimbangan lapangan (fiqh al-Waqi) dimana pada abad ini kekuasan kolonial berada pada puncak kekuatannya, hal ini ditandai dengan penghapusan tiga kesultanan Islam yaitu Kesultanan Palembang (1820 M), Kesultanan Banjarmasin (1860 M), danKesultanan Aceh (1873 M ), penghapusan ini yang melatarbelakangi beberapa

621.

${ }^{48}$ Hamka, Sejarah Ummat Islam, (Singapura: Pustaka Nasional, 2005), h.

${ }^{49}$ Badri Yatim, Op. Cit, h. 41-42. 
jihad di sebagian wilayah di Indonesia, yaitu jihad Cilegon (930 Juli 1888)dan Jihad Aceh (1873). ${ }^{50} \mathrm{Kedua}$, pertimbangan kemaslahatan (Fiqh al-Maslahah), dimana sikap kooperatif dan bekerjasama lebih akan membawa dampak kemaslahatan yang lebih besar dibanding bahaya (mudharat) yang pasti ketika melakukan sebuah perlawanan, beberapa pertimbangan maslahat itu diantaranya, pertama, membuka peluang untuk lebih merealisasikan lima dasar-dasar objektif syariah (Maqasid al-shariah) yaitu: Hifdhu al-Din (Kewajiban menjaga agama), Hifdhu al-'Aqli (kewajiabn menjaga akal), Hifdhu al-Nafs ( Kewajiban menjaga jiwa), Hifdhu al-Trdi (Kewajiban menjaga kehormatan) dan Hifdhu al-Mal ( Menjaga Harta kekayaan).kedua, merealisasikan universalitas Islam melalui usaha perbaikan di bidang politik pemerintahan, ketiga, mengenal program dan strategi kolonial dalam usaha memperlemah kekuatan umat Islam, keempat, menghentikan program-program kolonial yang akan membawa bahaya kepada umat Islam, kelima, membuka peluang untuk membuat perundanganyang akan membawa maslahat umat.

\section{Kesimpulan}

Fakta-fakta diatas telah membuktikan bahwa tradisi politik kaum sufi yang memang sejak awal membawa Islam ke kawasan Nusantara telah membawa corak ajaran Islamyang syamil (sempurna) dan mutakamil (merangkumi seluruh aspek kehidupan), hal ini tidak terpisahkan dari pengaruh jaringan intelektual ulama Nusantara dan ulama luar Nusantara yang telah terjalin dengan sangat intens, berawal dari sebuah transmisi intelektual sehingga tumbuh dan berkembang menjadi jaringan kekuatan politikmelawan hegemoni kolonial, baik melalui perlawanan terbuka (offensive) seperti yang dilakukan Ahmad Khatib melalui jaringan tarekatnya maupun sikap kooperatif dan bekerja sama seperti yang ditampilkan

${ }^{50}$ Karel A.Steenbrink (1984), Beberapa Aspek tentang Islam di Indonesia Abad ke-19, (Jakarta: P.T. Bulan Bintang), cet. 1, h. 5, 52 dan 65. 
oleh kedua ulama Kalimantan Barat abad ke-20 yakni Muhammad Basuni Imran dan Guru Haji Isma'il Mundu.

\section{Daftar Pustaka}

Al Attas, Syed Naquib Some Aspects of Sufism as Understood and Practised among the Malays, ed. Shirle Gordon. Singapore: Malaysian Sociological Research Institute, 1963 Lumpur: ISTAC, 2001

al-Mawardi, Abu al-Hasan, al-Abkam al-Sultaniyyah Beirut: Dar al-Fikr, t.th.

al-Jawziyyah, Ibn Qayyim. al-Turuq al-Hukmiyyah Fì al-Siyāsah al-Shar'iyyah. Beirut: Dār al-Kutub al-'Ilmiyyah, t.t.

Arberry, Athur John. The Doctrine of the Sufis. England: Cambridge University Press, 1966

Ahmad, Shukri, Ismail Yusoff \& Hamzah, Pendekatan Dakwah Ulama Sufi Nusantara Abad ke-17M dan 18M: Suatu AnalisisPerbandingan dengan Pendekatan Dakwah Ulama Malaysia Abad ke-21. Prosiding Nadwah Ulama Nusantara (NUN) IV: Ulama Pemacu Transformasi Negara. IV, 25-26 November 2011

Al-Ghazali, al-Tibr al-Masbuk fî Nasibat al-Muluk,terj. Ahmadie Thaha dan Ilyas Ismail Bandung: Mizan, 1994,

al-Mubarafuri, Shafiyurrahman, al-Rahiq al-Makhtum Mesir:

Dar al-Wafa, 1430 H/ 2009 M.

A. Harris, Khalif Muammar, "Ilmu Ketatanegaraan Melayu Abad Ke-19: Kajian Terbadap Karya Raja Ali Haji," Sari International Journal Of The Malay World And Civilaisation. 29 (1) 2011

Azra, Azyumardi, Jaringan Ulama Timur Tengah dan Kepulauan Nusantara Abad XVII dan XVIII,c. 2, Bandung: penerbit Mizan, 1995 
Belanda, wester-afdeeling berdasarkan Bêsluit van den Minister van Staat, Gouverneur-Generaal van Nederlandsch-Indie, pada 27 Agustus 1849, No. 8 dan No. 40

Bousfield, John, " Islamic Philosophy in Sout-East Asia", dalam Islam in South-East Asia, ed. M.B. Hooker Leiden: British Istitute in South East Asia, 1983

Bruinessen, Martin Van, "Tarekat Dan Politik: Amalan Untuk Dunia Atau Akherat?," Majalah PesantrenVol. Ix No. 1, 1992.

- Tarekat Naqsybandiyah di Indonesia Bandung: Mizan, 1992

Effendy, Machrus, Riwayat Hidup dan Perjuangan Maha Raja Imam Sambas, Jakarta: P.T. Dian Kemilau, 1995.

Hamka, Sejarah Ummat Islam, c. 5 Singapura: Pustaka Nasional, 2005.

Hanafi, A, Orientalisme Ditinjau Menurut Kacamata Agama Quran dan Hadits) Jakarta: Pustaka al Husna, 1981,

Hanafi, A, Orientalisme Ditinjau Menurut Kacamata Agama (Quran dan Hadits), Jakarta: Pustaka al Husna, 1981

Haris, Didik M Nur, " Kitab Jadual Nikah karya Guru Haji Isma'il Mundu; Teks dan Analisis". Tesis Jabatan Fiqh dan Usul Universiti Malaya Malaysia, 2011.

Iqbal, Muhammad, Akar Tradisi Politik Sunni di Indonesia pada masa kerajaan Islam di Nusantara. ISLAMIC A, Vol. 6, No. 1, September 2011

Irwin, Graham,Borneo Abad Kesembilan Belas. Terj. Mohd. Nor Ghani dan Noraini Ismail, c. 2. Kuala Lumpur: Dewan Bahasa dan Pustaka, 2006.

Isma'il, A. Muis Mengenal Muhammad Basuni Mabaraja Raja Sambas). Pontianak: FISIP Universitas Tanjungpura, 1993.

Jabbar, Umar 'Abd, Kitab Siyar wa al-Tarajim ba'd ulamaina fi alQarn al-Rabi' al-'Ashr min al-Hijrah, c. 3. Jedah:Tihamah al-Kitab al-Arabi al-Su'udi, 1403 $\mathrm{H} / 1982 \mathrm{M}$. 
John Arberry, Athur, The Doctrine of the Sufis England: Cambridge University Press, 1966

Kartodirdjo, Sartono, "The Peasants' Revolt of Banten in 1888: The Religious Revival," dalam Reading on Islam in Southeast Asia, Ahmad Ibrahim et al., Singapore: Institute of Southeast Asia Studies, 1985 Pemberontakan Petani Banten 1988, Kondisi, Jalan peristiwa, dan Kelanjutannya: Sebuah Studi mengenai Gerakan Sosial di Indonesia, ed. Hasan Basari, Jakarta: Pustaka Jaya, 1984.

Musa, Pabali, "Latar Belakang Sosial Politik Tarekat Qadiriyah wa Naqsyabandiyah Ahmad Khatib Sambas", (Disertasi pasca sarjana, UIN, Jakarta, 2008. "Mubammad Basuni Imran (1883-1976,

Rekonstruksi Pemikiran Maharaja Imam Sambas-Kesultanan Sambas Kalimantan Barat(Tesis Program Magsiter Pemikiran Islam, IAIN Syarif Hidayatullah, 1999

Pijper, G.F.,Studien Over de Geschiedenis Van De Islam In Indonesia 1900-1950, Netherlands: E.J. Brill Leiden, 1977 Beberapa Studi tentang Sejarah Islam di Indonesia 1900-1950, terj. Tudjimah \& Yessy Augusdin Jakarta: UI Press, 1984,

Republika, Islamia : Tokoh-tokoh Orientalis di Indonesia. Kamis, 13 Agustus 2009.

Riva'I, Abbas., et al. Biografi Guru Haji Isma'il Mundu Mufti Kerajaan Kubu. Cet. 2, Pontianak: Kitara Creativision, 2008.

Shaghir,Wan Mohd, Wawasan Pemikiran Islam Ulama Asia Tenggara, j.6 Kuala Lumpur: Persatuan Pengkajian Khazanah Klasik Nusantara dan Khazanah Fathaniyah1425 H/2004 M.

, Penyebaran Islam dan silsilah ulama sejagat dunia Melayu, Seri 11 Kuala Lumpur: Persatuan Pegkajian Khazanah Klasik Nusantara dan Khazanah Fathaniyah, 2000.

Suminto, Aqib, Politik Islam Hindia Belanda Jakarta: LP3ES, 1996 
62 ljtimaiyya: Jurnal Pengembangan Masyarakat Islam 10 (1) (2017)

Shihab,Alwi, Islam Sufistik, Islam Pertama dan Pengarubnya Hingga Kini di Indonesia, Bandung: Mizan, 2001.

Srimulyati, Tasawuf Nusantara Rangkaian Mutiara Sufi Terkemuka, Jakarta: Kencana Prenada Media Group, 2006.

Steenbrink, Karel A. O, Beberapa Aspek tentang Islam di Indonesia Abad ke-19, cet. 1 Jakarta: P.T.Bulan Bintang, 1984

Taimiyah, Ibn, Minhâj al-Sunnah al-Nabawiyah, Juz 1 Riyadh: Maktabat al-Riyad al-Hadithah, t.tp.

Tim Peneliti Universitas Tanjung Pura (UNTAN), Pontianak: Istana di Kalimantan Barat, Untan, 2000).

Yatim, Badri, Sejarah Sosial Keagamaan Tanah Suci Hijaz, (Mekkah dan Madinah) 1800-1925. Ciputat: Logos, 1999. 